\title{
Contact Precaution: Acceptance of Health Professionals to Teaching Hospital
}

\author{
Hercília Oliveira dos Santos ${ }^{1}$, Marli de Carvalho Jericó ${ }^{1 *}$, \\ Viviane Decicera Colombo Oliveira1, Geraldo Magela de Faria Junior ${ }^{1}$, \\ Patrícia de Carvalho Jericó ${ }^{2}$, Pedro Paulo de Carvalho Jericó ${ }^{3}$, \\ Ingrid Gomes Campos Truzzi ${ }^{1}$, Angela Silveira Gagliardo Calil ${ }^{1}$
}

\author{
${ }^{1}$ Faculdade de Medicina de São José do Rio Preto (FAMERP), São José do Rio Preto, Brazil \\ ${ }^{2}$ Pontifícia Universidade Católica do Rio Grande do Sul, Porto Alegre, Brazil \\ ${ }^{3}$ Pontifícia Universidade Católica do Paraná, Curitiba, Brazil \\ Email: ^marlicj@hotmail.com
}

How to cite this paper: dos Santos, H.O., de Carvalho Jericó, M., Oliveira, V.D.C., de Faria Junior, G.M., de Carvalho Jericó, P., de Carvalho Jericó, P.P., Truzzi, I.G.C. and Calil, A.S.G. (2020) Contact Precaution: Acceptance of Health Professionals to Teaching Hospital. Open Journal of Nursing, 10, 551-562.

https://doi.org/10.4236/ojn.2020.105038

Received: March 22, 2020

Accepted: May 26, 2020

Published: May 28, 2020

Copyright $\odot 2020$ by author(s) and Scientific Research Publishing Inc. This work is licensed under the Creative Commons Attribution International License (CC BY 4.0).

http://creativecommons.org/licenses/by/4.0/

\begin{abstract}
The adoption by health professionals to the practice of patient isolation is a decision that reduces patients' risks of occupational exposure to potentially contaminated biological material and prevents nosocomial infections. Verify the compliance of health professionals to the practices of contact precautions in patients colonized by microorganisms in a teaching hospital. This was a prospective observational cohort study in a special-sized hospital located in southeastern Brazil. The observation of health professionals in delivery of health care to patients with contact precaution was performed regarding hand hygiene, use of overcoat, glove, and mask. We carried out 1502 observations involving the following professional categories: nursing technicians and/or nursing assistants $(\mathrm{n}=1028 ; 68.4 \%)$, nurses $(\mathrm{n}=200 ; 13.3 \%)$, physical therapists $(\mathrm{n}=185 ; 12.3 \%)$, and physicians $(\mathrm{n}=89 ; 5.9 \%)$, totaling 971.8 hours. Regarding the level of compliance of professionals to contact precaution practices with hand hygiene after the procedures, the use of overcoats, gloves, and masks, all were statistically significant $(\mathrm{p}<0.001)$ both globally and by professional category. Klebsiella pneumoniae was the most positive pathogen identified in laboratory tests. This study provided the mapping of the compliance of health professionals to the practices of contact precautions in order to support a safer management of patient care reducing the risks of Healthcare-Associated Infections (HAI). This study also showed that health professionals are using practice management to deal with their behavior to protect their health.
\end{abstract}




\section{Keywords}

Universal Precautions, Infection Control Services, Hospital, Patient Isolation, Drug Resistance, Microbial, Quality Indicators, Health Care, Process Assessment (Health Care)

\section{Introduction}

Healthcare-Associated Infection (HAI) is a public health problem that manifests during and after the patient's hospitalization [1]. HAI has been a matter of concern in health systems because it is a source of disruption to the patient and his family causing a strong social impact. It also increases patient's length of hospital stay and out-of-the-pocket spending. This transmission usually happens from the contact of professionals with patients, especially those who do not use protective and preventive measures [2].

Microorganisms such as bacteria, viruses, and fungi are the main causes of increased cases of HAI. So preventive measures should be taken to control these etiological agents [3].

A study carried out in the United States showed that HAIs result in up to US\$6.5 billion in healthcare expenses annually. Every year, HAI causes or contributes to the death of nearly 100,000 people. This is a cause for concern when it comes to treatment and prevention [4].

Although there are guidelines for isolation precaution measures, they are not always fully adopted by health professionals. The guidelines provide practical advice on how you can comply with the requirements of the Personal Protective Equipment at Work, such as handwashing, wearing gloves and gown. The regulations are based on the Brazilian Regulatory Standard NR6 on the use of personal protective equipment (PPE) in the workplace. PPE is used by healthcare professionals against health and safety risks at work. It is used by professionals with the objective of protecting and promoting safety and preventing contamination between professionals and patients. It must be of indispensable use for the entire team [5].

About $30 \%$ of cases of nosocomial infections can be prevented with an easy act such as hand hygiene, i.e. washing hands with soap and water and a hand sanitizer with at least $70 \%$ alcohol (gel). It is considered a simple, effective, and low-cost measure. It is necessary to consider that the hands possibly harbor microorganisms and can transmit them from one surface to another by direct contact with the skin or by fomites [6] [7].

In the 1980s, the Brazilian Ministry Health established the guidelines to regulate the hospital infection control. In 1982, the National Hospital Infection Control Program was created. All hospitals are mandated to possess a Hospital Infection Control Committee (HICC) by Federal Law 9431 (1997).

The HICC is composed of a multidisciplinary team capable of detecting cases 
of nosocomial infections, as well as staff training and setting standards for healthcare practice. HICC aims to establish the awareness to everyone working in the hospital environment is both individually and collectively responsible for establishing protective measures [8]. On the other hand, there is a great difficulty in establish which precautions should be accomplished by health professionals, since there are no validated instruments with all the necessary requirements in the literature [9].

Nurses may acquire an infection during the provision of nursing care because of occupational exposure to microorganisms [10].

The circulation of bacteria has made it even more difficult to treat some HAI [11]. With the advent of antimicrobial resistance, the full compliance of healthcare professionals to follow the contact precautions standards in the delivered care of carriers infected by these microorganisms has become essential, in order to avoid their dissemination in the hospital environment [12]. The main multidrug-resistant bacteria responsible for such complications are the Methicillin/Oxacillin-resistant Staphylococcus aureus, Enterobacteria, bacterias from CESP group (Citrobacter spp., Enterobacter spp., Serratia spp., and Providencia spp.), Vancomycin-resistant Enterococci, Klebsiella pneumoniae, and Acinetobacter sp., among others [11].

Colonization and infection with resistant microorganisms have been related to several factors, including long-term antimicrobial therapy, cross-transmission, length of hospital stay, invasive procedures, readmissions, death and increased costs [13]. In order to prevent the above events, nursing audits and personnel training is essential in the healthcare of patients requiring contact precautions. Low compliance to the guidelines for contact precaution measures sometimes represents a great challenge due to lack of professional qualification, long working hours, and behavioral influences among professionals [14].

\section{Objective}

Verify the compliance of health professionals to the practices of contact precautions in patients colonized by microorganisms in a teaching hospital.

\section{Method}

This was a prospective observational cohort study using a quantitative approach. The study was carried out in a high-complexity quaternary (708-bed) special teaching hospital located in southeastern Brazil. The hospital serves to users of the Unified Health System (SUS), as well as various groups health insurance and prepaid health plans. This institution provides inpatient and outpatient hospital care in various medical specialties, making an average of 46,000 inpatient and outpatient hospital care/month. The hospital performs highly complex procedures, such as the organ transplants (bone marrow transplant, liver transplant, kidney transplant, and heart transplant).

We used the convenience sampling to select the study sample. It corresponded 
to opportunities for direct and non-participant observation from March to October 2018.

Study subjects were all health personnel (nursing assistants and/or technicians, nurses, physical therapists, and physicians). They were audited through observation during healthcare of patients requiring contact precautions. We audit their compliance to the guidelines for contact precaution measures through a direct observation in situ in Inpatient Units (clinical and surgical) and Intensive Care Units (ICU) in the three work shifts (morning, afternoon, and night).

Prior to these observations, 16 nursing students were given theoretical and practical training comprising hand hygiene, use of cloaks, gloves and masks, besides practices adopted regarding healthcare to patients requiring contact precaution of contact due to resistant microorganisms. In addition, directives on how the audit instrument should be used throughout the observations were provided on.

We used an instrument adapted from the "Observer Manual” [15]. The WHO multimodal hand hygiene improvement strategy, composed of identification data, such as the name of the observer, date and duration of the sessions, institution, service, unit, and category of the observed professional. We select the following variables on contact precaution: 1) hand hygiene before and after a patient encounter; 2) donning of gown and 3) gloves upon entering a patient room, and doffing upon exit, and 4) mask. Patient characteristics were sex, age, outcome, and laboratory tests. We obtained all this information from the patient's electronic medical record.

In compliance with CNS Resolution 466/12, data collection was conducted only after approval by the Research Ethics Committee (Opinion \#1.653.492).

For the statistical analysis, we used Chi-square test, through the adherence test, to assess whether there was a difference in the use of prevention procedures by health professionals. Chi-square (independence test) to assess whether there was an association between the use or not of contact precaution methods versus the work shift of the healthcare professional, as well as for the patient's place of hospitalization versus the healthcare professional category that assisted the patient. Furthermore, the Kruskal-Wallis test was performed to evaluate the association between professional category and observation time, as well as shift and observation time. The Mann-Whitney test was used to assess the association between observation time and location. We considered $\mathrm{p}<0.05$ as significant for all comparisons. The statistical software SPSS (SPSS, version 19.0. Chicago, IL) was used for all tests.

\section{Results}

We carried out 1502 observations involving 58,305 $\min$ (971.8 hours). The average observation time was $38.8 \pm 21.4 \mathrm{~min}$, ranging from 15 to $210 \mathrm{~min}$, distributed into afternoon shift (888 patients; 59.1\%), morning shift (400 patients; $26.6 \%$ ), and night shift (214 patients; $14.2 \%$ ). 
Our data consist of observations made in 197 patients colonized with microorganisms. Of these, $87(44.2 \%)$ were women and $110(55.8 \%)$ men. The mean age was $57.5 \pm 18.5$ years, with a range from 13 to 93 years. Seventy-six $(38.6 \%)$ patients were referred to clinical ICU and $121(61.4 \%)$ were referred to clinical and surgical units. Regarding the outcome, 49 (24.9\%) patients died during the observation period.

Urine culture was the most frequently test collected from patients undergoing evaluation for infection (93 patients; $47.2 \%$ ). It was followed by other bacterium cultures ( $\mathrm{n}=38 ; 19.3 \%$ ), KPC in epidemiological surveillance cultures of samples of a rectal swab (32 patients; 16.2\%), tracheal aspirate culture (31 patients; $15.7 \%$ ), and blood culture (three patients; $1.5 \%$ ).

Among the pathogens found in laboratory tests, Klebsiella pneumoniae was the most frequent one (103 strains isolated); of these, 63 strains isolated $(61.2 \%)$ were obtained in clinical and surgical units, and 40 strains isolated (38.8\%) in ICU. It is noteworthy that $316(21.0 \%)$ observations were carried out in ICU and $1186(79.0 \%)$ in clinical and surgical inpatient units (Table 1).

Among the precaution contact variables, it was observed that in the afternoon shift, 474 (53.4\%) healthcare professionals performed hand hygiene before a patient encounter; 741 (83.4\%) healthcare professionals wear gowns, 852 (95.9\%) wear gloves. In the morning shift, hand hygiene after a patient encounter was performed by $280(70.0 \%)$ healthcare professionals, as well as the mask use wear by $150(16.2 \%)$ healthcare professionals at night shift (Table 2$)$. However, when evaluating all work shifts, it was found that hand hygiene after a patient encounter and the use of gloves were the measures most frequently adopted by health professionals. Differences were statistically significant with a $\mathrm{p}$ value of 0.04 and 0.05 , respectively (Table 2 ).

We observed $1228(81.7 \%)$ healthcare professionals on the nursing team. Our data was composed of 1028 (68.4\%) licensed practical nurses and/or nursing assistants, followed by 200 (13.3\%) registered nurses, 185 (12.3\%) physical therapists, and 89 (5.9\%) physicians. There was no statistically significant difference between the different professionals who attended the patient and the observation time of each professional $(\mathrm{p}=0.06)$.

Overall, regarding the variables of contact precaution, our findings showed that hand hygiene after the patient encounter was more frequent (66.40\%) than before the patient encounter (51.86\%). We also observed this in all professional categories investigated. Nursing assistants and technicians were the professionals who least adhered to this measure (61.00\%) (Table 3).

Thus, the results showed that hand hygiene after procedures was statistically significant $(\mathrm{p}<0.001)$. However, when we evaluated hand hygiene before procedures, only registered nurses' category showed statistical significance ( $\mathrm{p}<$ 0.001). Physical therapists were the professionals who least adhered to hand hygiene before procedures $(44.30 \%)$, followed by nursing assistants/ technicians. 
Table 1. Pathogen distribution in patients under contact precaution, according to the patient's hospitalization unit. São José do Rio Preto, SP, Brazil, 2019.

\begin{tabular}{ccc}
\hline Bacteria/fungi & ICU & IPCU \\
$\mathrm{n}(\%)$ & $63(61.2)$ \\
\hline Klebsiella pneumoniae & $40(38.8)$ & $8(72.7)$ \\
Enterobacter clocae & $3(27.3)$ & $17(53.1)$ \\
Acinetobacter baumannii & $15(46.9)$ & $20(83.3)$ \\
Escherichia coli & $4(16.7)$ & $4(66.7)$ \\
Proteus mirabilis & $2(33.3)$ & $3(50.0)$ \\
Staphylococcus aureus & $3(50.0)$ & $0(0.0)$ \\
Staphylococcus hominis & $1(100.0)$ & $5(50.0)$ \\
Staphylococcus epidemidis & $5(50.0)$ & $17(50.0)$ \\
Pseudomonas aeruginosa & $17(50.0)$ & $2(100.0)$ \\
Citrobacter freundii & $0(0.0)$ & $2(100.0)$ \\
Alcaligenes faecalis & $0(0.0)$ & $8(80.0)$ \\
Enterococcus faecalis & $2(20.0)$ & $1(33.3)$ \\
Streptococcus viridans & $2(66.7)$ & $1(100.0)$ \\
Stenotrophomonas maltophylia & $0(0.0)$ & $5(55.6)$ \\
Candida albicans & $4(44.4)$ & $1(50.0)$ \\
Candida tropicalis & $1(50.0)$ & $3(75.0)$ \\
Candida grabrata & $1(25.0)$ & $15(88.2)$ \\
\hline Others & $2(11.8)$ & \\
\hline
\end{tabular}

$\mathrm{ICU}=$ Intensive Care Unit; IPCU = Inpatient Care Units.

Table 2. Distribution of the compliance to precaution contact, according to healthcare professionals’ work shift. São José do Rio Preto, SP, Brazil, 2019.

\begin{tabular}{|c|c|c|c|c|}
\hline Contact Precaution & $\begin{array}{l}\text { Morning } \\
\mathrm{n}(\%)\end{array}$ & $\begin{array}{c}\text { Afternoon } \\
\mathrm{n}(\%)\end{array}$ & $\begin{array}{l}\text { Night } \\
\mathrm{n}(\%)\end{array}$ & $\mathrm{p}$-Value \\
\hline Hand washing before & & & & 0.11 \\
\hline yes & $298(52.0)$ & $474(53.4)$ & $97(45.3)$ & \\
\hline no & $192(48.0)$ & $414(46.6)$ & $117(54.7)$ & \\
\hline Hand washing after & & & & 0.04 \\
\hline yes & $280(70.0)$ & $128(59.8)$ & $589(66.3)$ & \\
\hline no & $120(30.0)$ & $86(40.2)$ & $299(33.7)$ & \\
\hline Gown & & & & 0.10 \\
\hline yes & $328(82.0)$ & $741(83.4)$ & $165(77.1)$ & \\
\hline no & $72(18.0)$ & $147(16.6)$ & $49(22.9)$ & \\
\hline Gloves & & & & 0.05 \\
\hline yes & $372(93.0)$ & $852(95.9)$ & $199(93.0)$ & \\
\hline no & $28(7.0)$ & $36(4.1)$ & $15(7.0)$ & \\
\hline Mask & & & & 0.07 \\
\hline yes & $55(13.8)$ & $24(11.2)$ & $150(16.2)$ & \\
\hline no & $345(86.3)$ & $190(88.8)$ & $738(83.1)$ & \\
\hline
\end{tabular}


Table 3. Distribution of compliance to contact precaution variables, according to professional category. São José do Rio Preto. SP. Brazil.

\begin{tabular}{|c|c|c|c|c|c|c|c|c|c|c|}
\hline \multirow{2}{*}{$\begin{array}{c}\text { Prof Cat } \\
\text { Precaution }\end{array}$} & \multicolumn{2}{|c|}{ Globally } & \multicolumn{2}{|c|}{ Nurse } & \multicolumn{2}{|c|}{ N.A./LPN. } & \multicolumn{2}{|c|}{ Physio Therapist } & \multicolumn{2}{|c|}{ Physician } \\
\hline & $\mathrm{B}^{\star} \cdot \mathrm{n}(\%)$ & $\mathrm{A}^{*} \cdot \mathrm{n}(\%)$ & $\mathrm{B}^{\star} \cdot \mathrm{n}(\%)$ & $\mathrm{A}^{*} \cdot \mathrm{n}(\%)$ & $\mathrm{B}^{\star} \cdot \mathrm{n}(\%)$ & $\mathrm{A}^{\star} \cdot \mathrm{n}(\%)$ & $\mathrm{B}^{\star} \cdot \mathrm{n}(\%)$ & A.n (\%) & $\mathrm{B}^{\star} \cdot \mathrm{n}(\%)$ & $\mathrm{A}^{\star} \cdot \mathrm{n}(\%)$ \\
\hline \multicolumn{11}{|c|}{$H H$} \\
\hline Yes & 779 (51.86) & $997(66.40)$ & $141(70.50)$ & $161(80.50)$ & $499(48.50)$ & $627(61.00)$ & $103(55.70)$ & $144(77.80)$ & $36(40.40)$ & $65(73.00)$ \\
\hline No & $723(48.13)$ & $505(33.60)$ & $59(29.50)$ & 39 (19.50) & $529(51.5)$ & $401(39.00)$ & $82(44.30)$ & $41(22.20)$ & $53(59.60)$ & $24(27.00)$ \\
\hline $\mathrm{p}$ & 0.15 & $<0.001$ & $<0.001$ & $<0.001$ & 0.35 & $<0.001$ & 0.12 & $<0.001$ & 0.07 & $<0.001$ \\
\hline \multicolumn{11}{|c|}{ Gown } \\
\hline Yes & $1.234(82.20)$ & & $174(87.00)$ & & $814(79.20)$ & & $179(96.80)$ & & $67(75.30)$ & \\
\hline No & $268(17.80)$ & & $26(13.00)$ & & $214(20.80)$ & & $6(3.20)$ & & $22(24.70)$ & \\
\hline $\mathrm{p}$ & $<0.001$ & & $<0.001$ & & $<0.001$ & & $<0.001$ & & $<0.001$ & \\
\hline \multicolumn{11}{|c|}{ Gloves } \\
\hline Yes & $1.423(94.70)$ & & $188(94.00)$ & & $970(94.40)$ & & $182(98.40)$ & & $83(83.30)$ & \\
\hline No & $79(5.30)$ & & $12(6.00)$ & & $58(5.60)$ & & $3(1.6)$ & & $6(6.70)$ & \\
\hline $\mathrm{p}$ & $<0.001$ & & $<0.001$ & & $<0.001$ & & $<0.001$ & & $<0.001$ & \\
\hline \multicolumn{11}{|c|}{ Mask } \\
\hline Yes & $229(15.20)$ & & $21(10.50)$ & & $81(7.90)$ & & $115(62.20)$ & & $12(13.50)$ & \\
\hline No & $1.273(84.80)$ & & $179(89.50)$ & & $947(92.10)$ & & $70(87.80)$ & & $77(86.50)$ & \\
\hline $\mathrm{p}$ & $<0.001$ & & $<0.001$ & & $<0.001$ & & 0.001 & & $<0.001$ & \\
\hline
\end{tabular}

Professional Category; ${ }^{\star} \mathrm{B}=$ Before patient encounter; ${ }^{\star} \mathrm{A}$ : After patient encounter; A = Nursing assistant; LPN = License practical nurse; ${ }^{\star} \mathrm{HH}$; Hands HYGIENE.

Analyzing the global use of Personal Protective Equipment (EPP) in patients requiring contact precaution, we identified that the use of gloves represented (94.70\%), gowns (82.20\%), and masks (15.20\%). Physical therapists were the professionals who most frequently used gown $(96.80 \%)$, glove $(98.40 \%)$, and mask (62.20\%).

The medical team had the lowest compliance rate to the guidelines on the use of gowns $(75.30 \%)$, and gloves (83.30\%). The use of a mask was lower among nursing assistants/technicians (7.90\%). However, when we evaluated the overall situation, as well as all categories, we observed that the use of gown and glove was statistically significant $(\mathrm{p}<0.001)$. This did not occur in relation to the use of masks. Regarding the use of PPE, the statistical significance was not using this PPE.

\section{Discussion}

In our study, almost $60 \%$ of the patients observed were male. A study showed that the notion men had about healthcare, indicates their vulnerability to infections. Besides, the risk of men getting involved in a fatal event, is greater than that of women. The study also reports there are a greater number of hospitalized men in serious situations, and generally they live less than women [16]. 
We observed the precaution contact measures in 197 individuals. Of these, 63 patients (61.2\%) colonized with Klebsiella pneumoniae were in clinical and surgical units. At the Hospital e Maternidade Therezinha de Jesus, located in is a city in the southeastern Brazilian state of Minas Gerais, 193 patients were investigated. Of these, $17.09 \%$ acquired Nosocomial infections by Klebsiella pneumoniae. It is a major cause of morbidity and mortality worldwide. It typically causes infections in hospitalized patients or otherwise in those with chronic diseases [17].

Given the factors directly linked to the growth of Healthcare-Related Infections (HAI), healthcare providers may play a role in the spread of microorganisms, and if they do not comply with the precaution contact guidelines, they will not be able to take the necessary measures to prevent infections [18].

Regarding the variables of contact precaution, our findings showed that hand hygiene was done more frequently after a patient encounter than before a patient encounter (66.40\% and 51.86\%, respectively). This was statistically significant ( $\mathrm{p}$ $<0.001$ ) when we observed all professional both globally and by categories.

The professional category most frequently performing hand hygiene was nursing personnel, both before and after a patient encounter $(70.50 \%$ and $80.50 \%$, respectively). However, when we evaluated hand hygiene before patient encounter, only nurses' category presented statistical significance $(\mathrm{p}<0.001)$. It is worth remembering that the hands are the main instrument used by nurses in the care process.

A study carried out in an adult ICU of a public university hospital in the metropolitan area of Belo Horizonte, the capital of the state of Minas Gerais, applied a questionnaire and made a direct observation of the care provided to patients on contact precaution. The study reported a compliance rate of hand hygiene of $87.9 \%$, while the observed rate reported was $19.0 \%$. This reveals that the use of the questionnaire leads most professionals to report answers that are socially and scientifically accepted. However, this does not mean that they fulfill them in their professional practice. Professionals reported factors that hinder adherence to hand hygiene such as forgetfulness, lack of knowledge, distance from washbasins, and skin irritation caused by the antiseptic product [19].

Our results indicated that the healthcare professionals that most frequently used gowns were physical therapists (96.80\%). An experience report carried out at a private hospital discussed precaution contact measures for healthcare professionals while they were delivering care to an infected patient. Physical therapists reported that the use of a gown as Personal Protective Equipment (PPE) does not disturb the team routines. However, nursing personnel reported discomfort with the use of a gown, mainly due to the excessive heat generated during the bed bath [20].

An integrative review reported the use of gloves was directly linked to handwashing. This means that hand disinfection procedure is critical even if wearing gloves. Healthcare professionals not always have a wise perception in the use of gloves. Many of them use it only when dealing with visible bodily secretions and 
feces. Others may not have enough knowledge to comply with protective measures, or there is a lack of time and motivation to follow this standard. Professionals need educational and awareness measures to trigger behavioral change [21].

Mask was most frequently personal protective equipment used by physical therapists $(62.20 \%)$. According to the institutional protocols, at the present study, the use of a mask is recommended to maintain aseptic conditions or to administer inhaled anesthetics or other gases, as well as to protect from the risk of extensive splashing/spraying of blood and/or other body fluids. Licensed practical nurses did not use a mask to perform the management of such procedures, according to an integrative review [22].

It is noteworthy that the use of gown, glove, and mask was statistically significant $(\mathrm{p}<0.001)$, both globally and throughout categories. A precaution contact study conducted in the United States, involving 1013 observations of a variety of healthcare professionals, administrative personnel, and general service categories, revealed that the nursing team (30.8\%), followed by physical therapist (27.9\%) were the ones that complied with all stages of contact precaution [4].

There is a concern to the nursing team, because besides composing the largest number of professionals in health institutions, it is the category that provides most of the direct patient care. A study revealed that the nursing team was more exposed to infections than physicians ( $41 \%$ and $31 \%$, respectively) [23].

Contact precaution is intended to prevent transmission of microorganisms, which are spread by direct or indirect contact with the patient or the patient's environment. These include hand hygiene; use of gloves, gown, mask, eye protection, or face shield, depending on the anticipated exposure; and safe injection practices. The preferred placement for patients who require contact precautions is in an isolation room. When the healthcare team does not follow the precaution standards, the dissemination of pathogens can occur among professionals and patients, which results in a cross-transmission, leading to increased rates of nosocomial infection and other serious consequences [21].

It is important to promote healthcare training with longer periods of time intervals between sessions addressing the Personal Protective Equipment (PPE) guidelines, as well as to propose a quarterly recycling model for adequate updating of the multidisciplinary team. The literature states that newly graduated professionals tend to follow more institutional protocols when compared to those who have many years of experience once they are at risk of not recycling their knowledge over time [23] [24].

\section{Conclusion}

This study provided the mapping of compliance to contact precaution performed by health professionals in all stages investigated. It highlighted relevant information for a safer healthcare management of the patient with contact precaution, reducing the risk of HAI, as well as in the behavior management of health professionals for the protection of their own health. 


\section{Study Limitations}

The availability of students' time to make observations about the healthcare professionals' compliance to contact precaution standards was one of the limiting factors of the study, which is why there were more observations in the afternoon shift.

\section{Study's Contributions}

HO, GM, PJ, PJ, IGCT and ASGC wrote the manuscript. MCJ and VDCO revised the manuscript. All the authors read and approved the final manuscript.

\section{Funding Sources}

None.

\section{Conflicts of Interest}

The authors declare no conflicts of interest regarding the publication of this paper.

\section{References}

[1] Paz, M.C.F., et al. (2015) Análise da infecção hospitalar em um hospital universitário na paraíba no período de 2012 a 2014. Revista Saúde e Ciência Online, 4, 31-43.

[2] Oliveira, A.C., et al. (2010) Infecção hospitalar em unidade de tratamento intensivo de um hospital universitário brasileiro. Rev. Latino-Am. Enfermagem, 18, 97-104.

[3] Ferreira, E.F.S., et al. (2013) Um desafio para o controlador de infecção: Falta de adesão da enfermagem às medidas de prevenção e controle. Enfermería Global, 31, 331.

[4] Dhar, S., et al. (2014) Contact Precautions: More Is Not Necessarily Better. Infection Control and Hospital Epidemiology, 35, 213-219. https://doi.org/10.1086/675294

[5] Pinel, J.S., et al. (2010) Educação continuada: Importância do uso de EPI durante manipulação de pacientes em precaução de contato. Revista Online de Pesquisa: cuidado É Fundamental, 2, 829-831.

[6] Primo, M.G.B., et al. (2010) Adesão à prática de higienização das mãos por profissionais de saúde de um Hospital Universitário. Revista Eletrônica de Enfermagem, 12, 266-271. http://www.fen.ufg.br/revista/v12/n2/v12n2a06.htm https://doi.org/10.5216/ree.v12i2.7656

[7] Galdino, H.J., et al. (2015) Adesão e conhecimento de profissionais da saúde em relação às precauções para aerossóis. Rev Rene, 16, 514-521.

[8] Puccini, P.T., et al. (2011) Perspectivas do controle da infecção hospitalar e as novas forças sociais em defesa da saúde. Ciência \& Saúde Coletiva, 16, 3043-3049. https://doi.org/10.1590/S1413-81232011000800004

[9] Malaguti-Toffano, S.E., Santos, C.B., Canini, S.R.M.S., Galvão, M.T.G., Brevidelli, M.M. and Gir, E. (2012) Adesão às precauções-padrão de profissionais de enfermagem de um hospital universitário. Acta Paul Enferm, 25, 401-407. https://doi.org/10.1590/S0103-21002012000300013

[10] Campos, S.F., et al. (2011) Biossegurança: Conhecimento e Adesão às Medidas de Precauções Padrão num Hospital. Revista Brasileira de Ciências da Saúde, 15, 415-420. 
https://doi.org/10.4034/RBCS.2011.15.04.06

[11] Silva, A.R.A., Werneck, L. and Henriques, C.T. (2012) Dinâmica da circulação de bactérias multirresistentes em unidades de terapia intensiva pediátrica do Rio de Janeiro. Journal of Epidemiology and Infection Control, 2, 41-45. https://doi.org/10.17058/reci.v2i2.2500

[12] Moura, M.E.B., Campelo, S.M.A., Brito, F.C.P., Batista, O.M.A., Araújo, T.M.E. and Oliveira, A.D.S. (2007) Infecção hospitalar: Estudo de prevalência em um hospital público de ensino. Revista Brasileira de Enfermagem: Brasília, 60, 416-421. https://doi.org/10.1590/S0034-71672007000400011

[13] Arcanjo, R.A. and Oliveira, A.C. (2014) Resistência Bacteriana em Unidade de Terapia Intensiva: Análise de Incidência e Fatores de Risco Associados. Journal of Infection Control, 3, No. 4.

[14] Lacerda, M.K.S., et al. (2014) Precauções padrão e Precauções Baseadas na Transmissão de doenças: revisão de literatura. Journal of Epidemiology and Infection Control, 4, 254-259. https://doi.org/10.17058/reci.v4i4.4952

[15] Organização Pan-Americana da Saúde, Agência Nacional de Vigilância Sanitária; Manual para observadores: Estratégia multimodal da OMS para a melhoria da higienização das mãos. Organização Mundial da Saúde; tradução de Sátia MarineBrasília: Organização Pan-Americana da Saúde; Agência Nacional de Vigilância Sanitária. 2008. http://www.saude.df.gov.br/wp-conteudo/uploads/2018/02/2.4.1.pdf

[16] da Costa-Júnior, F.M. (2009) Concepções de Homens Hospitalizados sobre a Relação entre Gênero e Saúde. Psicologia: Teoria e Pesquisa, 25, 55-63.

http://www.scielo.br/pdf/ptp/v25n1/a07v25n1 https://doi.org/10.1590/S0102-37722009000100007

[17] da Silva Perna, T.D.G., et al. (2015) Prevalência de infecção hospitalar pela bactéria do gênero Klebsiella em uma Unidade de Terapia Intensiva. Revista da Sociedade Brasileira de Clínica Médica, 13, 119-123.

[18] Reinato, L.A.F., Pereira, F.M.V., Lopes, L.P., Pio, D.P.M. and Gir, E. (2015) Nasal Colonization in Nursing Professionals from Units Specialized in HIV/AIDS. Revista Brasileira de Enfermagem, 68, 320-324. https://doi.org/10.1590/0034-7167.2015680119i

[19] Oliveira, A.C., et al. (2017) Monitorização da higienização das mãos: Observação direta versus taxa autorreportada. Enfermería Global, 48, 334. https://digitum.um.es/xmlui/bitstream/10201/54417/1/277861-1044261-1-PB.pdf

[20] Alvim, A.L.S. and Santos, F.C.R. (2017) Medidas de Precaução de Contato para Prevenção e Controle de Infecções: Relato de Experiência. Revista de Enfermagem do Centro-Oeste Mineiro, 7, e1333. https://doi.org/10.19175/recom.v7i0.1333

[21] Padilha, J.M.F.O., Sá, S.P.C. and Silvino, Z.R. (2017) Luvas e adesão de profissionais de enfermagem às precauções de contato: Uma revisão integrativa. Revista de Enfermagem UFPE on Line, 11, 667-674.

https://periodicos.ufpe.br/revistas/revistaenfermagem/article/viewFile/11986/14546

[22] da Silva, O.M., et al. (2018) Biossegurança E Precaução Padrão Na Unidade De Terapia Intensiva: Revisão Integrativa. Revista Uningá, 49, No. 1. http://revista.uninga.br/index.php/uninga/article/view/1302

[23] Souza, A.C.S., Silva, C.F., Tipple, A.F.V., Santos, S.L.V. and Neves, H.C.C. (2008) O uso de equipamentos de proteção individual entre graduandos de cursos da área da saúde e a contribuição das instituições formadoras. Ciência, Cuidado E Saúde, 7, 27-36. https://doi.org/10.4025/cienccuidsaude.v7i1.4893 
[24] Gómez-La Rotta, E.I., et al. (2015) Conhecimento e adesão às precauções padrão: Estudantes diante dos riscos biológicos no Brasil e na Colômbia. Revista de Salud Pública, 17, 429-442. https://doi.org/10.15446/rsap.v17n3.44907 